Monitoring for PCBs at the Pilot Plant Complex, Aberdeen Proving Ground

$\therefore \backslash F D$

DEC 201995

OSTI

Energy Systems Division

Argonne National Laboratory

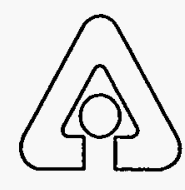

Operated by The University of Chicago,

under Contract W-31-109-Eng-38, for the

United States Department of Energy

DISTARUTION OF. THS DOCUMENT IS LALEMTED 


\section{Argonne National Laboratory}

Argonne National Laboratory, with facilities in the states of Illinois and Idaho, is owned by the United States Government, and operated by the University of Chicago under the provisions of a contract with the Department of Energy.

This technical memo is a product of Argonne's Energy Systems (ES) Division. For information on the division's scientific and engineering activities, contact:

\section{Director, Energy Systems Division \\ Argonne National Laboratory \\ Argonne, Illinois 60439-4815 \\ Telephone (708) 252-3724}

Presented in this technical memo are preliminary results of ongoing work or work that is more limited in scope and depth than that described in formal reports issued by the ES Division.

Publishing support services were provided by Argonne's Information and Publishing Division (for more information, see IPD's home page: http://www.jpd.anl.gov/).

\section{Disclaimer}

This report was prepared as an account of work sponsored by an agency of the United States Government. Neither the United States Government nor any agency thereof, nor any of their employees, makes any warranty, express or implied, or assumes any legal liability or responsibility for the accuracy, completeness, or usefulness of any information, apparatus, product, or process disclosed, or represents that its use would not infringe privately owned rights. Reference herein to any specific commercial product, process, or service by trade name, trademark, manufacturer, or otherwise, does not necessarily constitute or imply its endorsement, recommendation, or favoring by the United States Government or any agency thereof. The views and opinions of authors expressed herein do not necessarily state or reflect those of the United States Government or any agency thereof.

Reproduced directly from the best available copy.

Available to DOE and DOE contractors from the Office of Scientific and Technical Information, P.O. Box 62, Oak Ridge, TN 37831; prices available from (423) 576-8401.

Available to the public from the National Technical Information Senvice, U.S. Department of Commerce, 5285 Port Royal Road, Springfield, VA 22161. 


\section{DISCLAIMER}

Portions of this document may be illegible in electronic image products. Images are produced from the best available original document. 


\section{Monitoring for PCBs at the Pilot Plant Complex, Aberdeen Proving Ground}

by J.F. Schneider, H.J. O'Neill, V.J. Cohut, D.C. Hayes, D.P. O'Reilly, and R.E. Zimmerman

Center for Environmental Restoration Systems, Energy Systems Division, Argonne National Laboratory, 9700 South Cass Avenue, Argonne, Illinois 60439

July 1995

Work sponsored by United States Department of Defense, United States Army, Aberdeen Proving Ground, Maryland 
This report is printed on recycled paper. 


\section{Contents}

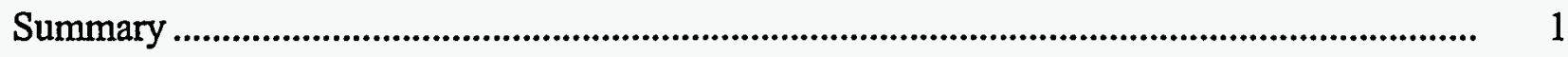

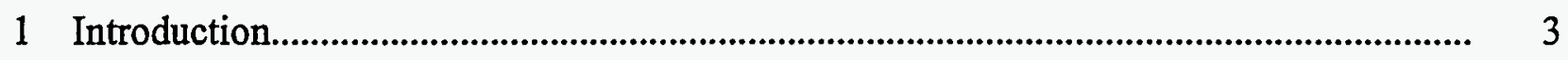

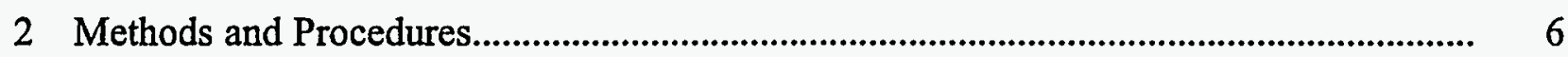

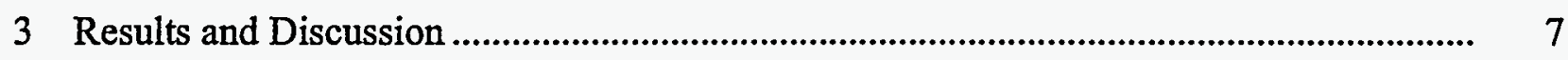

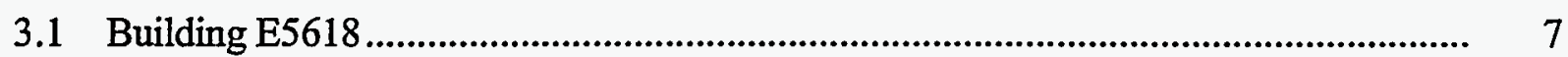

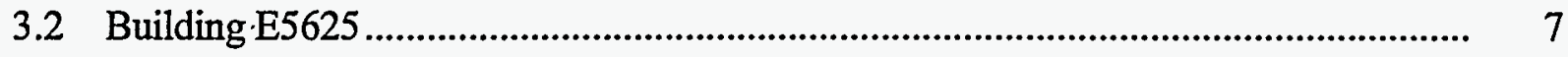

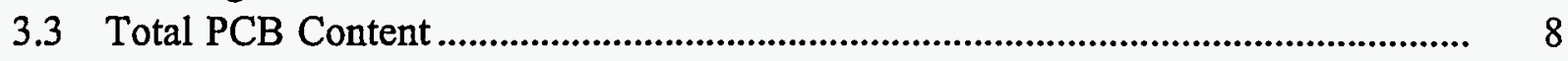

4 Quality Assurance/Quality Control ........................................................................ 17

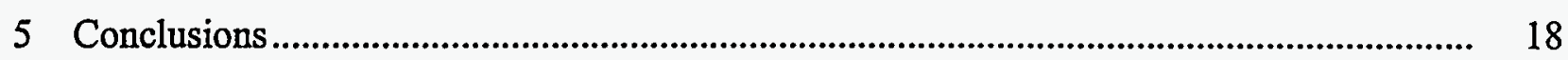

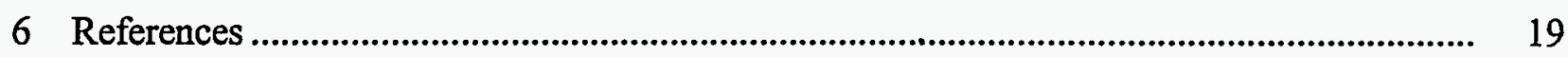

\section{Tables}

1 Results of PCB Screening of the Pilot Plant Complex.............................................

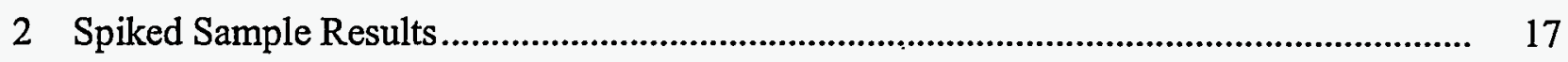

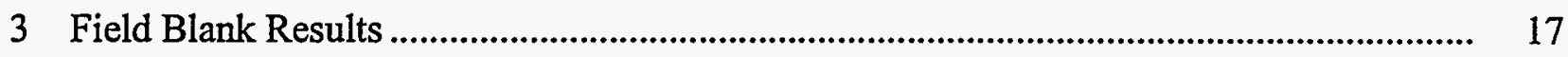

\section{Figures}

1 Location of Aberdeen Proving Ground ...................................................................... 4

2 General Layout of the Pilot Plant Complex........................................................... 5

3 Layout of Building E5618, Showing Sampling Points .............................................. 14

4 Layout of the First Floor of Building E5625, Showing Sampling Points.......................... 14

5 Layout of the' Second Floor of Building E5625, Showing Sampling Points....................... 15

6 Layout of the Third Floor of Building E5625, Showing Sampling Points ....................... 15 
Figures (Cont.)

7 Layout of the Fourth Floor of Building E5625, Showing Sampling Points ......................... 16

8 Layout of the Roof of Building E5625, Showing Sampling Points ..................................... 16 


\title{
Monitoring for PCBs at the \\ Pilot Plant Complex, Aberdeen Proving Ground
}

by

\author{
J.F. Schneider, H.J. O’Neill, V.J. Cohut, D.C. Hayes, \\ D.P. O'Reilly, and R.E. Zimmerman
}

\section{Summary}

The U.S. Army's Aberdeen Proving Ground has been a test site for a variety of munitions, including chemical warfare agents. The Pilot Plant Complex (PPC) at Aberdeen was the site of the development, manufacture, storage, and disposal of a number of chemical warfare agents. The objective of this study was to determine if there is polychlorinated biphenyl (PCB) contamination in the PPC.

The air in the PPC was sampled and analyzed for volatile organic compounds by Argonne National Laboratory in fall 1994, at which time PCBs were identified at low levels (1-50 ng/L) in some areas. The OSHA-allowable PCB exposure level for workers is $500 \mathrm{ng} / \mathrm{L}$ (time-weighted average). In this study, additional sampling for PCBs was done by taking wipe samples in areas suspected of having PCB contamination. The PCB survey of the PPC was intended to determine the relative degree of contamination present in the PPC and to assess whether the various structures exhibit PCB levels that exceed either the threshold limit value ${ }^{*}$ of $0.5 \mathrm{mg} / \mathrm{m}^{3}$ (skin exposure value for Aroclor 1254) or the workplace exposure levelt of $10 \mu \mathrm{g} / 100 \mathrm{~cm}^{2}$.

The results of screening done by Argonne indicate that PCBs in the air of the PPC are well below acceptable levels. The total PCB burden of the surfaces in the PPC appears to be well below the 50-ppm regulatory level. $\ddagger$ However, the study identified contaminated floor surfaces that exceed the acceptable level of $10 \mu \mathrm{g} / 100 \mathrm{~cm}^{2}$ for a workplace. Areas in Building E5618 exceed $1,000 \mu \mathrm{g} / 100 \mathrm{~cm}^{2}$, with a high reading of $21,100 \mu \mathrm{g} / 100 \mathrm{~cm}^{2}$ in room $\mathrm{C} 103$. Building E5625 has several areas where PCBs exceed $100 \mu \mathrm{g} / \mathrm{cm}^{2}$.

\footnotetext{
* American Conference of Governmental Industrial Hygienists.

$\dagger$ (40 CFR 761.125).

$\ddagger$ (40 CFR 761.60).
} 


\section{Introduction}

The U.S. Army's Aberdeen Proving Ground (APG) has been the test site for a variety of munitions, including chemical warfare agents (CWA). The Pilot Plant Complex (PPC) at APG was the site of the development, manufacture, storage, and disposal of CWA. The PPC is located in the Edgewood Area (EA) of Aberdeen, which is situated 21 miles northeast of Baltimore, in the Atlantic Coastal Plain, in an area to the west of Chesapeake Bay (Figure 1). The area in which the PPC is located sits in the Canal Creek basin. The complex, originally designated Complex 87 , was constructed in 1941 prior to the entry of the United States into World War II; it contains nine buildings, as shown in Figure 2 .

The complex was closed in 1986. Since that time, all equipment, piping, and conduit in the buildings have been removed. The buildings have been sampled and declared free of surface CWA contamination as a result of air sampling by using the military system (Lattin 1994).

The air in the PPC was sampled and analyzed for volatile organic compounds by Argonne National Laboratory (ANL) in fall 1994, at which time polychlorinated biphenyls (PCBs) were identified at low levels (1-50 ng/L) in some of the areas (Schneider et al. 1995). The OSHAallowable PCB exposure level for workers is $500 \mathrm{ng} / \mathrm{L}$ (time-weighted average). Consequently, wipe sampling for PCBs was performed to determine the relative degree of contamination present in the PPC and to assess whether the various structures exhibit PCB levels that exceed either the threshold limit value ${ }^{*}$ of $0.5 \mathrm{mg} / \mathrm{m}^{3}$ (skin exposure value for Aroclor 1254) or the workplace exposure levelt of $10 \mathrm{mg} / 100 \mathrm{~cm}^{3}$. In addition, the PCB survey will supply supporting information as to whether the total PCB burden of the PPC will exceed the regulatory level $(50 \mathrm{ppm})$ for classifying demolition rubble as hazardous waste. $\ddagger$

\footnotetext{
${ }^{*}$ American Conference of Governmental Industrial Hygienists.

$\dagger$ (40 CFR 761.125).

$\ddagger(40$ CFR 761.60).
} 


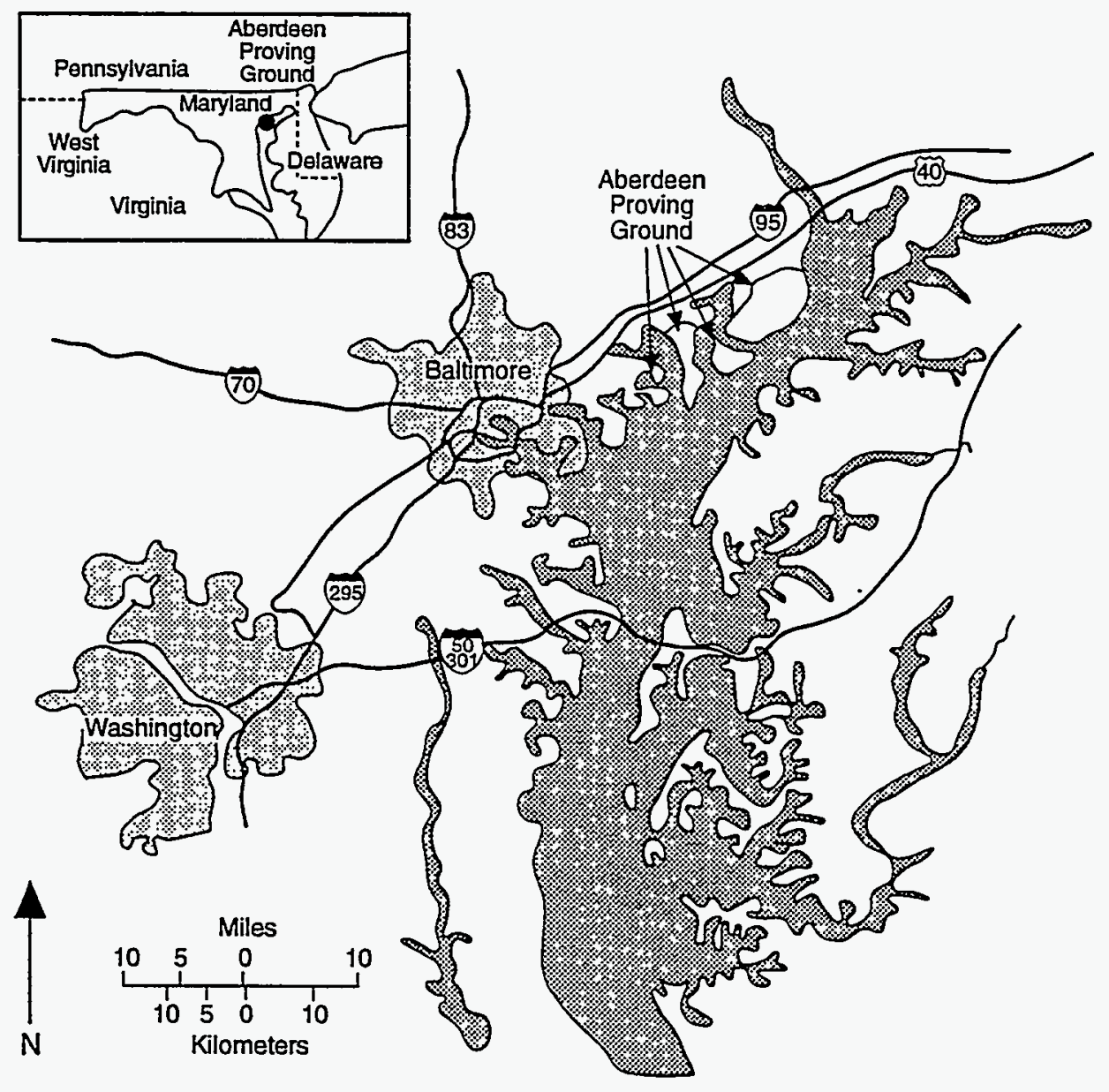

FIGURE 1 Location of Aberdeen Proving Ground 


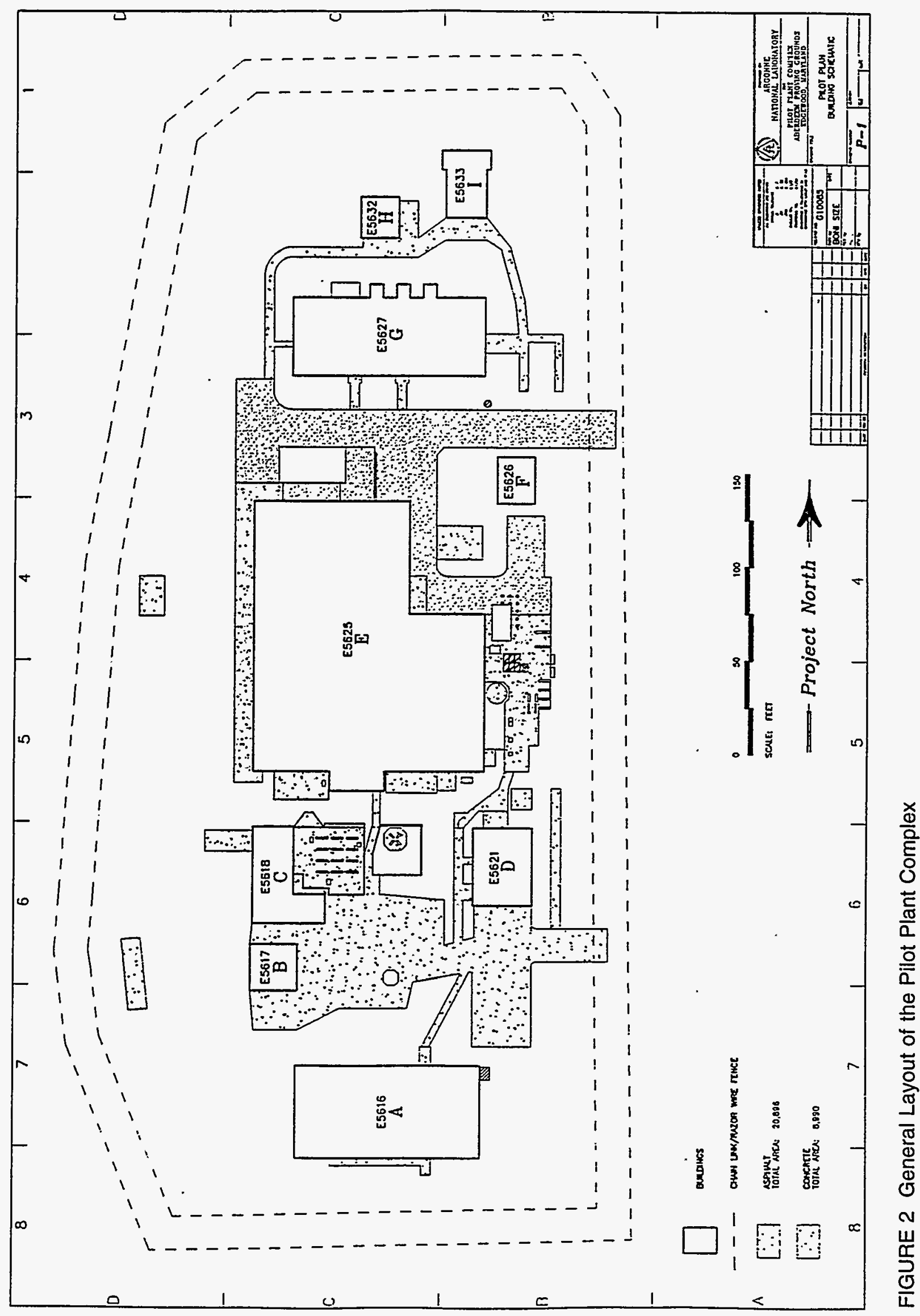




\section{Methods and Procedures}

Preliminary ambient air monitoring of the PPC was performed in order to assess the relative degree of contamination present (Schneider et al. 1995). On the basis of the ambient air monitoring data, selected rooms in Building E5625 and all the rooms in Building E5618 were monitored for PCBs. A visual "walk-through" inspection yielded several locations that required sampling, on the basis of the presence of stains or spill marks on the floor that may represent PCB material. In each instance, the perimeter of the soil mark was outlined with a paint stripe to mark its location.

A standard operating procedure, SOP \#103 (O’Neill et al. 1994), identifies the procedures followed by ANL for the measurement of PCBs. Generally, Environmental Protection Agency (EPA) guidelines were followed in collecting wipe samples. All samples were sent off-site to a commercial analytical laboratory for PCB analysis.

In performing this survey of the buildings composing the PPC, any PCB contamination present was assumed to be due to the leakage or spillage of PCB-containing electrical equipment, compressors, hydraulic systems, or transformers and, consequently, to be located on the floors. The results of the preliminary ambient-air monitoring survey (Schneider et al. 1995) had indicated that levels of PCBs present in the air were elevated (compared to general outdoor background levels). In view of the possibility that PCB contamination may exist on the ceilings and walls of the buildings, the PPC was surveyed at night with a fluorescent lamp to determine whether additional PCB contamination could be identified. Time did not permit a survey of the entire PPC. However, a survey of the "high-risk" areas in Building E5618 did indicate the presence of a $\sim 3$-ft-diameter fluorescent spot on the wall (C05) in Room C-102. This large area of fluorescent contamination has not yet been identified, but its presence demonstrates that additional survey activity should be initiated at the PPC to clarify the nature of this material and to determine whether any other contaminated areas exist. 


\section{Results and Discussion}

Analytical results are presented in Table 1. A discussion of each sampling location is given below. Refer to Figure 3 (page 14) for the sampling locations in Building E5618 and to Figures 4-8 (pages 14-16) for the sampling locations in Building E5625.

\subsection{Building E5618}

- C101. Wipe samples showed no detectable levels of PCBs.

- C102. Wipe samples indicated the presence of PCBs (Aroclors 1248, 1254, and 1260) on the floor at levels of 44 to $117 \mu \mathrm{g} / 100 \mathrm{~cm}^{2}$.

- C103. Wipe samples showed significant levels of PCBs (Aroclors 1248, 1254, and 1260), as high as $21,100 \mu \mathrm{g} / 100 \mathrm{~cm}^{2}$ on spill-stained floor surfaces. This area needs to be remediated.

- C104. Wipe samples showed significant levels of PCBs (Aroclors 1248, 1254, and 1260), as high as $16,000 \mu \mathrm{g} / 100 \mathrm{~cm}^{2}$ on the floor. This area needs to be remediated.

\subsection{Building E5625}

- E123. Wipe samples indicated the presence of PCBs (Aroclors 1248 and 1254), with a high reading of $56 \mu \mathrm{g} / 100 \mathrm{~cm}^{2}$.

- E131. Wipe samples indicated the presence of PCBs (Aroclors 1248, 1254, and 1260), with a high reading of $84 \mu \mathrm{g} / 100 \mathrm{~cm}^{2}$.

- E207. Wipe samples indicated the presence of PCBs (Aroclors 1248, 1254, and 1260 ), with a high reading of $80 \mu \mathrm{g} / 100 \mathrm{~cm}^{2}$.

- E220. Wipe samples indicated the presence of PCBs (Aroclors 1248, 1254, and 1260), with a high reading of $305 \mu \mathrm{g} / 100 \mathrm{~cm}^{2}$.

- E305: Wipe samples of a drain indicated relatively low levels of PCBs as Aroclor $1254\left(27 \mu \mathrm{g} / 100 \mathrm{~cm}^{2}\right.$ was the highest reading). 
- E314. Wipe samples indicate the presence of PCBs (Aroclors 1248, 1254, and 1260 ), with a high reading of $350 \mu \mathrm{g} / 100 \mathrm{~cm}^{2}$.

- E319. Wipe samples indicate the presence of PCBs (Aroclors 1248, 1254, and 1260 ), with a high reading of $281 \mu \mathrm{g} / 100 \mathrm{~cm}^{2}$.

- E416. Wipe samples indicate the presence of PCBs (Aroclors 1248 and 1254), with a high reading of $127 \mu \mathrm{g} / 100 \mathrm{~cm}^{2}$.

- E417. Wipe samples indicate the presence of PCBs (Aroclors 1248 and 1254), with a high reading of $112 \mu \mathrm{g} / 100 \mathrm{~cm}^{2}$.

- E504. Wipe samples indicated the presence of PCBs (Aroclors 1248, 1254, and 1260 ), with a high reading of $124 \mu \mathrm{g} / 100 \mathrm{~cm}^{2}$.

\subsection{Total PCB Content}

The total amount of PCBs that would need to be present in the PPC in order to exceed the $50-\mathrm{ppm}$ demolition-rubble concentration, as based on a total rubble value of 11,000 tons, amounts to approximately $1,230 \mathrm{lb}(557,000 \mathrm{~g})$. Considering the surface area of the floors in the PPC $\left(\sim 49,000,000 \mathrm{~cm}^{2}\right)$, the average floor surface would have to contain $1,136,000 \mu \mathrm{g} / 100 \mathrm{~cm}^{2}$ to obtain the $50-\mathrm{ppm}$ concentration. The highest reading obtained in this investigation was $21,100 \mu \mathrm{g} / 100 \mathrm{~cm}^{2}$, and the average reading in areas targeted as being most likely to contain contamination was $530 \mu \mathrm{g} / 100 \mathrm{~cm}^{2}$. Therefore, on the basis of the results of this study, and assuming that no "pockets" of PCB contamination exist below surfaces of the PPC, the estimated total building burden is in the range of $50 \mathrm{ppb}$, which is three orders of magnitude below the allowable level. 
TABLE 1 Results of PCB Screening of the Pilot Plant Complex

\begin{tabular}{|c|c|c|c|c|c|c|c|c|c|c|c|c|}
\hline \multirow{2}{*}{$\begin{array}{c}\text { Sample } \\
\text { No. }\end{array}$} & \multirow{2}{*}{$\begin{array}{c}\text { Wipe } \\
\text { No. }\end{array}$} & \multicolumn{8}{|c|}{ Aroclor Concentration ${ }^{a}\left(\mu \mathrm{g} / 100 \mathrm{~cm}^{2}\right)$} & \multirow[b]{2}{*}{ Total } & \multirow{2}{*}{$\begin{array}{c}\text { Detection } \\
\text { Limit } \\
(\mu \mathrm{g})\end{array}$} & \multirow{2}{*}{$\begin{array}{l}\text { Spike } \\
\text { Value } \\
(\mu g)\end{array}$} \\
\hline & & 1016 & 1221 & 1232 & 1242 & 1248 & 1254 & 1260 & 1262 & & & \\
\hline \multicolumn{13}{|c|}{ Building E5618 } \\
\hline \multirow[t]{4}{*}{ C101 } & 1 & BDL & BDL & BDL & BDL & BDL & BDL & BDL & $\mathrm{BDL}$ & 0 & 2.5 & - \\
\hline & 2 & BDL & BDL & BDL & BDL & BDL & BDL & BDL & BDL & 0 & 2.5 & - \\
\hline & 3 & BDL & BDL & BDL & $\mathrm{BDL}$ & $\mathrm{BDL}$ & BDL & BDL & BDL & 0 & 2.5 & - \\
\hline & 4 & BDL & BDL & BDL & BDL & $B D L$ & $\mathrm{BDL}$ & BDL & BDL & 0 & 2.5 & - \\
\hline \multirow[t]{7}{*}{ C102 } & 5 & BDL & BDL & BDL & BDL & 75.0 & 22.0 & 17.0 & BDL & 114 & 2.5 & - \\
\hline & 6 & BDL & BDL & $\mathrm{BDL}$ & $\mathrm{BDL}$ & 56.0 & 23.0 & $\mathrm{BDL}$ & BDL & 79 & 2.5 & - \\
\hline & 7 & BDL & BDL & BDL & BDL & 34.0 & 12.0 & 12.0 & BDL & 58 & 2.5 & - \\
\hline & 8 & BDL & BDL & BDL & BDL & 51.0 & 50.0 & 16.0 & BDL: & 117 & 2.5 & - \\
\hline & 9 & $\mathrm{BDL}$ & BDL & BDL & BDL & 30.0 & 14.0 & $\mathrm{BDL}$ & BDL & 44 & 2.5 & - \\
\hline & 10 & BDL & BDL & $\mathrm{BDL}$ & BDL & $B D L$ & BDL & $\mathrm{BDL}$ & BDL & 0 & 2.5 & Blank \\
\hline & 11 & BDL & BDL & $\mathrm{BDL}$ & $\mathrm{BDL}$ & BDL & 8.7 & $\mathrm{BDL}$ & $\mathrm{BDL}$ & 9 & 2.5 & $10(1254)$ \\
\hline \multirow[t]{11}{*}{$\mathrm{C} 103$} & 12 & BDL & BDL & BDL & BDL & 150.0 & 67.0 & 12.0 & BDL & 229 & 2.5 & - \\
\hline & 13 & BDL & BDL & $\mathrm{BDL}$ & BDL & 200.0 & 86.0 & 13.0 & BDL & 299 & 2.5 & - \\
\hline & 14 & BDL & BDL & BDL & BDL & 160.0 & 64.0 & 37.0 & BDL & 261 & 2.5 & - \\
\hline & 15 & BDL & BDL & BDL & BDL & 87.0 & 38.0 & 16.0 & BDL & 141 & 2.5 & - \\
\hline & 16 & $\mathrm{BDL}$ & BDL & BDL & BDL & $3,100.0$ & $3,300.0$ & $1,200.0$ & BDL & 7,600 & 125 & - \\
\hline & 17 & $\mathrm{BDL}$ & BDL & $\mathrm{BDL}$ & $\mathrm{BDL}$ & $13,000.0$ & $6,200.0$ & $1,900.0$ & BDL & 21,100 & 250 & - \\
\hline & 18 & BDL & BDL & BDL & $\mathrm{BDL}$ & 130.0 & 77.0 & 100.0 & BDL & 307 & 2.5 & - \\
\hline & 19. & BDL & BDL & BDL & BDL & 48.0 & 43.0 & 12.0 & BDL & 103 & 2.5 & - \\
\hline & 20 & BDL & BDL & BDL & BDL & 67.0 & 48.0 & 56.0 & BDL & 171 & 2.5 & - \\
\hline & 21 & $\mathrm{BDL}$ & BDL & $\mathrm{BDL}$ & $\mathrm{BDL}$ & BDL & 5.9 & $\mathrm{BDL}$ & BDL & 6 & 2.5 & $10(1254)$ \\
\hline & 22 & $\mathrm{BDL}$ & BDL & BDL & $\mathrm{BDL}$ & BDL & $\mathrm{BDL}$ & BDL & $\mathrm{BDL}$ & 0 & 2.5 & Blank \\
\hline \multirow{7}{*}{ C104 } & 23 & $\mathrm{BDL}$ & BDL & BDL & $\mathrm{BDL}$ & 460.0 & 320.0 & 120.0 & BDL & 900 & 13 & - \\
\hline & 24 & $\mathrm{BDL}$ & BDL & BDL & BDL & 380.0 & 350.0 & 100.0 & BDL & 830 & 25 & - \\
\hline & 25 & $\mathrm{BDL}$ & $\mathrm{BDL}$ & BDL & BDL & 260.0 & 85.0 & 22.0 & BDL & 367 & 5 & - \\
\hline & 26 & BDL & BDL & $\mathrm{BDL}$ & BDL & 430.0 & 72.0 & $\mathrm{BDL}$ & BDL & 502 & 10 & - \\
\hline & 27 & BDL & BDL & BDL & BDL & 440.0 & $1,700.0$ & 540.0 & BDL & 2,680 & 50 & - \\
\hline & 28 & $\mathrm{BDL}$ & BDL & BDL & $\mathrm{BDL}$ & $2,800.0$ & $9,400.0$ & $3,800.0$ & BDL & 16,000 & 125 & - \\
\hline & 29 & $\mathrm{BDL}$ & BDL & BDL & BDL & 100.0 & 57.0 & 93.0 & $\mathrm{BDL}$ & 250 & 5 & - \\
\hline
\end{tabular}


TABLE 1 (Cont.)

\begin{tabular}{|c|c|c|c|c|c|c|c|c|c|c|c|c|}
\hline \multirow{2}{*}{$\begin{array}{c}\text { Sample } \\
\text { No. }\end{array}$} & \multirow{2}{*}{$\begin{array}{l}\text { Wipe } \\
\text { No. }\end{array}$} & \multicolumn{8}{|c|}{ Aroclor Concentration ${ }^{\mathrm{a}}\left(\mu \mathrm{g} / 100 \mathrm{~cm}^{2}\right)$} & \multirow[b]{2}{*}{ Total } & \multirow{2}{*}{$\begin{array}{c}\text { Detection } \\
\text { Limit } \\
(\mu \mathrm{g})\end{array}$} & \multirow{2}{*}{$\begin{array}{l}\text { Spike } \\
\text { Value } \\
(\mu \mathrm{g})\end{array}$} \\
\hline & & 1016 & 1221 & 1232 & 1242 & 1248 & 1254 & 1260 & 1262 & & & \\
\hline \multicolumn{13}{|c|}{ Building E5618 (Cont.) } \\
\hline & 30 & $\mathrm{BDL}$ & BDL & BDL & $\mathrm{BDL}$ & BDL & $\mathrm{BDL}$ & $\mathrm{BDL}$ & BDL & 0 & 2.5 & Blank \\
\hline & 31 & $\mathrm{BDL}$ & BDL & $\mathrm{BDL}$ & $\mathrm{BDL}$ & BDL & 79.0 & 7.4 & BDL: & 86 & 2.5 & $100(1254)$ \\
\hline \multicolumn{13}{|c|}{ Building E5625 } \\
\hline \multirow[t]{5}{*}{ E123 } & 32 & $\mathrm{BDL}$ & BDL & BDL & $\mathrm{BDL}$ & 42.0 & 14.0 & $\mathrm{BDL}$ & $\mathrm{BDL}$ & 56 & 2.5 & - \\
\hline & 33 & $\mathrm{BDL}$ & $\mathrm{BDL}$ & BDL & BDL & 14.0 & $\mathrm{BDL}$ & $\mathrm{BDL}$ & BDL & 14 & 2.5 & - \\
\hline & 34 & BDL & $B D L$ & $\mathrm{BDL}$ & BDL & BDL & 4.0 & $\mathrm{BDL}$ & BDL & 4 & 2.5 & - \\
\hline & 35 & $\mathrm{BDL}$ & $\mathrm{BDL}$ & BDL & $\mathrm{BDL}$ & 15.0 & 12.0 & BDL & $\mathrm{BDL}$ & 27 & 2.5 & - \\
\hline & 36 & $\mathrm{BDL}$ & $\mathrm{BDL}$ & BDL & BDL & $\mathrm{BDL}$ & 7.1 & $\mathrm{BDL}$ & $\mathrm{BDL}$ & 7 & 2.5 & - \\
\hline \multirow[t]{10}{*}{ E131 } & 37 & $\mathrm{BDL}$ & $\mathrm{BDL}$ & BDL & $\mathrm{BDL}$ & $\mathrm{BDL}$ & 3.4 & $\mathrm{BDL}$ & BDL & 3 & 2.5 & - \\
\hline & 38 & $\mathrm{BDL}$ & $\mathrm{BDL}$ & $\mathrm{BDL}$ & $\mathrm{BDL}$ & 6.7 & 26.0 & 8.5 & BDL & 41 & 2.5 & - \\
\hline & 39 & $\mathrm{BDL}$ & $\mathrm{BDL}$ & BDL & BDL & $\mathrm{BDL}$ & 26.0 & 16.0 & $\mathrm{BDL}$ & 42 & 2.5 & - \\
\hline & 40 & $\mathrm{BDL}$ & $\mathrm{BDL}$ & $\mathrm{BDL}$ & $\mathrm{BDL}$ & $\mathrm{BDL}$ & $\mathrm{BDL}$ & $\mathrm{BDL}$ & BDL & 0 & 2.5 & Blank \\
\hline & 41 & $\mathrm{BDL}$ & $\mathrm{BDL}$ & $\mathrm{BDL}$ & $\mathrm{BDL}$ & $\mathrm{BDL}$ & $\mathrm{BDL}$ & 40.0 & $\mathrm{BDL}$ & 40 & 2.5 & $\begin{array}{ll}10 & (1016) \\
50 & (1260)\end{array}$ \\
\hline & 42 & $\mathrm{BDL}$ & $\mathrm{BDL}$ & $\mathrm{BDL}$ & $\mathrm{BDL}$ & 42.0 & 29.0 & $\mathrm{BDL}$ & BDL & 71 & 2.5 & - \\
\hline & 43 & BDL & $\mathrm{BDL}$ & $\mathrm{BDL}$ & $\mathrm{BDL}$ & 55.0 & 29.0 & $\mathrm{BDL}$ & BDL & 84 & 2.5 & - \\
\hline & 44 & BDL & $\mathrm{BDL}$ & $\mathrm{BDL}$ & BDL & 24.0 & 34.0 & BDL & $\mathrm{BDL}$ & 58 & 2.5 & - \\
\hline & 45 & $\mathrm{BDL}$ & $\mathrm{BDL}$ & $\mathrm{BDL}$ & $\mathrm{BDL}$ & 21.0 & 27.0 & $\mathrm{BDL}$ & $\mathrm{BDL}$ & 48 & 2.5 & - \\
\hline & 46 & $\mathrm{BDL}$ & $\mathrm{BDL}$ & $\mathrm{BDL}$ & $\mathrm{BDL}$ & 4.1 & $\mathrm{BDL}$ & $\mathrm{BDL}$ & $\mathrm{BDL}$ & 4 & 2.5 & - \\
\hline \multirow[t]{7}{*}{ E207 } & 47 & $\mathrm{BDL}$ & $\mathrm{BDL}$ & $\mathrm{BDL}$ & $\mathrm{BDL}$ & 24.0 & 46.0 & 10.0 & $\mathrm{BDL}$ & 80 & 2.5 & - \\
\hline & 48 & BDL & $\mathrm{BDL}$ & $\mathrm{BDL}$ & $\mathrm{BDL}$ & 26.0 & 45.0 & $\mathrm{BDL}$ & $\mathrm{BDL}$ & 71 & 2.5 & - \\
\hline & 49 & $\mathrm{BDL}$ & $\mathrm{BDL}$ & BDL & $\mathrm{BDL}$ & 9.1 & $\mathrm{BDL}$ & $\mathrm{BDL}$ & $\mathrm{BDL}$ & 9 & 2.5 & - \\
\hline & 50 & $\mathrm{BDL}$ & BDL & $\mathrm{BDL}$ & BDL & $\mathrm{BDL}$ & $\mathrm{BDL}$ & $\mathrm{BDL}$ & BDL & 0 & 2.5 & Blank \\
\hline & 51 & $\mathrm{BDL}$ & BDL & BDL & 42 & $\mathrm{BDL}$ & $\mathrm{BDL}$ & $\mathrm{BDL}$ & $\mathrm{BDL}$ & 42 & 2.5 & $\begin{aligned} 50 & (1016) \\
5 & (1260)\end{aligned}$ \\
\hline & 52 & $\mathrm{BDL}$ & $\mathrm{BDL}$ & BDL & BDL & BDL & 9.3 & $\mathrm{BDL}$ & BDL & 9 & 2.5 & - \\
\hline & 53 & $\mathrm{BDL}$ & BDL & BDL & BDL & 51.0 & 70.0 & 12.0 & BDL & 133 & 2.5 & - \\
\hline \multirow[t]{3}{*}{ E220 } & 54 & $\mathrm{BDL}$ & $\mathrm{BDL}$ & $\mathrm{BDL}$ & BDL & BDL & 21.0 & $\mathrm{BDL}$ & BDL & 21 & 2.5 & - \\
\hline & 55 & $\mathrm{BDL}$ & BDL & $\mathrm{BDL}$ & $\mathrm{BDL}$ & $\mathrm{BDL}$ & 12.0 & BDL & $\mathrm{BDL}$ & 12 & 2.5 & - \\
\hline & 56 & $\mathrm{BDL}$ & $\mathrm{BDL}$ & $\mathrm{BDL}$ & $\mathrm{BDL}$ & $\mathrm{BDL}$ & 9.3 & $\mathrm{BDL}$ & $\mathrm{BDL}$ & 9 & 2.5 & - \\
\hline
\end{tabular}


TABLE 1 (Cont.)

\begin{tabular}{|c|c|c|c|c|c|c|c|c|c|c|c|c|c|}
\hline \multirow{2}{*}{$\begin{array}{c}\text { Sample } \\
\text { No. }\end{array}$} & \multirow{2}{*}{$\begin{array}{c}\text { Wipe } \\
\text { No. }\end{array}$} & \multicolumn{8}{|c|}{ Aroclor Concentration ${ }^{a}\left(\mu \mathrm{g} / 100 \mathrm{~cm}^{2}\right)$} & \multirow[b]{2}{*}{ Total } & \multirow{2}{*}{$\begin{array}{c}\text { Detection } \\
\text { Limit } \\
(\mu \mathrm{g})\end{array}$} & \multirow{2}{*}{\multicolumn{2}{|c|}{$\begin{array}{l}\text { Spike } \\
\text { Value } \\
(\mu g)\end{array}$}} \\
\hline & & 1016 & 1221 & 1232 & 1242 & 1248 & 1254 & 1260 & 1262 & & & & \\
\hline \multicolumn{14}{|c|}{ Building E5625 (Cont.) } \\
\hline E220 & 57 & $\mathrm{BDL}$ & $\mathrm{BDL}$ & BDL & BDL & BDL & 13.0 & BDL & BDL & 13 & 2.5 & & - \\
\hline & 58 & BDL & BDL & BDL & BDL & 48.0 & 41.0 & BDL & BDL & 89 & 2.5 & & - \\
\hline & 59 & $\mathrm{BDL}$ & $\mathrm{BDL}$ & $\mathrm{BDL}$ & $\mathrm{BDL}$ & 36.0 & 57.0 & BDL & $\mathrm{BDL}$ & 93 & 2.5 & & - \\
\hline & 60 & $\mathrm{BDL}$ & $\mathrm{BDL}$ & BDL & BDL & BDL & $\mathrm{BDL}$ & BDL & $\mathrm{BDL}$ & 0 & 2.5 & & Blank \\
\hline & 61 & BDL & BDL & BDL & BDL & $\mathrm{BDL}$ & 85.0 & BDL & $\mathrm{BDL}$ & 85 & 2.5 & 100 & $(1254)$ \\
\hline & 62 & $\mathrm{BDL}$ & BDL & BDL & BDL & 40.0 & 71.0 & BDL & $\mathrm{BDL}$ & 111 & 2.5 & & - \\
\hline & 63 & BDL & BDL & $\mathrm{BDL}$ & BDL & $\mathrm{BDL}$ & 25.0 & BDL & BDL & 25 & 2.5 & & - \\
\hline & 64 & BDL & BDL & BDL & BDL & 52.0 & 95.0 & 27.0 & $\mathrm{BDL}$ & 174 & 2.5 & & - \\
\hline & 65 & BDL & BDL & BDL & BDL & 30.0 & 37.0 & 13.0 & BDL & 80 & 2.5 & & - \\
\hline & 66 & BDL & BDL & BDL & BDL & 40.0 & 59.0 & BDL & BDL & 99 & 2.5 & & - \\
\hline & 67 & $\mathrm{BDL}$ & BDL & BDL & BDL & 95.0 & 130.0 & BDL & $\mathrm{BDL}$ & 225 & 2.5 & & - \\
\hline & 68 & $\mathrm{BDL}$ & BDL & $\mathrm{BDL}$ & BDL & 16.0 & 58.0 & 4.8 & $\mathrm{BDL}$ & 79 & 2.5 & & - \\
\hline & 69 & $\mathrm{BDL}$ & BDL & $\mathrm{BDL}$ & BDL & 36.0 & 78.0 & BDL & $B D L$ & 114 & 2.5 & & - \\
\hline & 70 & $\mathrm{BDL}$ & BDL & BDL. & BDL & BDL & BDL & $B D L$ & BDL & 0 & 2.5 & & Blank \\
\hline & 71 & $\mathrm{BDL}$ & BDL & $\mathrm{BDL}$ & 7.3 & BDL & BDL & 41.0 & $\mathrm{BDL}$ & 48 & 2.5 & $\begin{array}{l}10 \\
50\end{array}$ & $\begin{array}{l}(1016) \\
(1260)\end{array}$ \\
\hline & 72 & BDL & BDL & $\mathrm{BDL}$ & BDL & 27.0 & 64.0 & $\mathrm{BDL}$ & $\mathrm{BDL}$ & 91 & 2.5 & & - \\
\hline & 73 & $\mathrm{BDL}$ & BDL & BDL & BDL & BDL & 38.0 & BDL & BDL & 38 & 2.5 & & - \\
\hline & 74. & BDL & BDL & $\mathrm{BDL}$ & $\mathrm{BDL}$ & BDL & 48.0 & BDL & $\mathrm{BDL}$ & 48 & 2.5 & & - \\
\hline & 75 & $\mathrm{BDL}$ & BDL & $\mathrm{BDL}$ & BDL & BDL & 78.0 & 23.0 & BDL & 101 & 2.5 & & - \\
\hline & 76 & $\mathrm{BDL}$ & BDL & $\mathrm{BDL}$ & BDL & 46.0 & 240.0 & 19.0 & $\mathrm{BDL}$ & 305 & 10 & & - \\
\hline & 77 & BDL & BDL & BDL & BDL & 17.0 & 41.0 & 13.0 & $\mathrm{BDL}$ & 71 & 2.5 & & $\therefore$ \\
\hline & 78 & $\mathrm{BDL}$ & $\mathrm{BDL}$ & $\mathrm{BDL}$ & $\mathrm{BDL}$ & $\mathrm{BDL}$ & 4.3 & BDL & BDL & 4 & 2.5 & & - \\
\hline & 79 & $\mathrm{BDL}$ & $\mathrm{BDL}$ & $\mathrm{BDL}$ & $\mathrm{BDL}$ & $\mathrm{BDL}$ & 5.8 & 3.1 & $\mathrm{BDL}$ & 9 & 2.5 & & - \\
\hline & 80 & BDL & $\mathrm{BDL}$ & BDL & 42 & $\mathrm{BDL}$ & BDL & BDL & $\mathrm{BDL}$ & 42 & 2.5 & $\begin{array}{r}50 \\
5\end{array}$ & $\begin{array}{l}(1016) \\
(1260)\end{array}$ \\
\hline & 81 & BDL & $\mathrm{BDL}$ & $\mathrm{BDL}$ & BDL & BDL & 25.0 & BDL & $\mathrm{BDL}$ & 25 & 2.5 & & - \\
\hline
\end{tabular}


TABLE 1 (Cont.)

\begin{tabular}{|c|c|c|c|c|c|c|c|c|c|c|c|c|}
\hline \multirow{2}{*}{$\begin{array}{c}\text { Sample } \\
\text { No. }\end{array}$} & \multirow{2}{*}{$\begin{array}{c}\text { Wipe } \\
\text { No. }\end{array}$} & \multicolumn{8}{|c|}{ Aroclor Concentration ${ }^{a}\left(\mu \mathrm{g} / 100 \mathrm{~cm}^{2}\right)$} & \multirow[b]{2}{*}{ Total } & \multirow{2}{*}{$\begin{array}{c}\text { Detection } \\
\text { Limit } \\
(\mu \mathrm{g})\end{array}$} & \multirow{2}{*}{$\begin{array}{l}\text { Spike } \\
\text { Value } \\
(\mu \mathrm{g})\end{array}$} \\
\hline & & 1016 & 1221 & 1232 & 1242 & 1248 & 1254 & 1260 & 1262 & & & \\
\hline \multicolumn{13}{|c|}{ Building E5625 (Cont.) } \\
\hline & 82 & $\mathrm{BDL}$ & BDL & $\mathrm{BDL}$ & BDL & $\mathrm{BDL}$ & 26.0 & $\mathrm{BDL}$ & $\mathrm{BDL}$ & 26 & 2.5 & - \\
\hline & 83 & $\mathrm{BDL}$ & BDL & $\mathrm{BDL}$ & BDL & BDL & 18.0 & BDL & BDL & 18 & 2.5 & - \\
\hline \multirow[t]{6}{*}{ E305 } & 87 & $\mathrm{BDL}$ & BDL & BDL & $\mathrm{BDL}$ & BDL & 21.0 & $\mathrm{BDL}$ & $\mathrm{BDL}$ & 21 & 2.5 & - \\
\hline & 88 & $\mathrm{BDL}$ & $\mathrm{BDL}$ & $\mathrm{BDL}$ & $\mathrm{BDL}$ & $\mathrm{BDL}$ & 27.0 & BDL & $\mathrm{BDL}$ & 27 & 2.5 & - \\
\hline & 89 & BDL & $\mathrm{BDL}$ & BDL & $\mathrm{BDL}$ & BDL & 2.8 & $\mathrm{BDL}$ & BDL. & 3 & 2.5 & - \\
\hline & 90 & $\mathrm{BDL}$ & BDL & $\mathrm{BDL}$ & $\mathrm{BDL}$ & BDL & 3.2 & $\mathrm{BDL}$ & BDL & 3 & 2.5 & - \\
\hline & 91 & $\mathrm{BDL}$ & $\mathrm{BDL}$ & BDL & $\mathrm{BDL}$ & BDL & 4.8 & $\mathrm{BDL}$ & $\mathrm{BDL}$ & 5 & 2.5 & - \\
\hline & 92 & BDL & $\mathrm{BDL}$ & BDL & $\mathrm{BDL}$ & BDL & 5.3 & BDL & BDL & 5 & 2.5 & - \\
\hline \multirow[t]{8}{*}{ E314 } & 93 & BDL & BDL & BDL & BDL & BDL & 350.0 & $\mathrm{BDL}$ & BDL & 350 & 10 & - \\
\hline & 94 & BDL & $\mathrm{BDL}$ & $\mathrm{BDL}$ & BDL & 20.0 & 120.0 & 20.0 & BDL & 160 & 2.5 & - \\
\hline & 95 & BDL & BDL & BDL & BDL & BDL & 58.0 & $\mathrm{BDL}$ & $\mathrm{BDL}$ & 58 & 2.5 & - \\
\hline & 96 & $\mathrm{BDL}$ & BDL & $\mathrm{BDL}$ & $\mathrm{BDL}$ & 32.0 & 210.0 & 23.0 & $\mathrm{BDL}$ & 265 & 2.5 & - \\
\hline & 97 & $\mathrm{BDL}$ & BDL & BDL & BDL & $\mathrm{BDL}$ & 170.0 & 16.0 & BDL & 186 & 2.5 & - \\
\hline & 98 & $\mathrm{BDL}$ & BDL & $\mathrm{BDL}$ & BDL & 37.0 & 82.0 & $\mathrm{BDL}$ & BDL & 119 & 2.5 & - \\
\hline & 99 & BDL & BDL & BDL & BDL & 54.0 & 69.0 & BDL & BDL & 123 & 2.5 & - \\
\hline & 100 & BDL & BDL & BDL & BDL & 26.0 & 59.0 & BDL & BDL & 85 & 2.5 & -. \\
\hline \multirow[t]{3}{*}{ E319 } & 101 & $\mathrm{BDL}$ & BDL & BDL & BDL & 110.0 & 160.0 & 11.0 & $\mathrm{BDL}$ & 281 & 2.5 & - \\
\hline & 102 & $\mathrm{BDL}$ & $\mathrm{BDL}$ & BDL & BDL & 39.0 & 42.0 & 4.2 & BDL & 85 & 2.5 & - \\
\hline & 103. & BDL & BDL & $\mathrm{BDL}$ & BDL & 55.0 & 140.0 & 13.0 & BDL & 208 & 2.5 & - \\
\hline \multirow[t]{5}{*}{ E416 } & 114 & BDL & BDL & BDL & BDL & 87.0 & 39.0 & $\mathrm{BDL}$ & BDL & 126 & 2.5 & - \\
\hline & 115 & $\mathrm{BDL}$ & BDL & BDL & BDL & 49.0 & 49.0 & $\mathrm{BDL}$ & BDL & 98 & 2.5 & - \\
\hline & 116 & BDL & BDL & BDL & BDL & 60.0 & 67.0 & $\mathrm{BDL}$ & $\mathrm{BDL}$ & 127 & 2.5 & - \\
\hline & 117 & BDL & BDL & BDL & BDL & 50.0 & 27.0 & BDL & BDL & 77 & 2.5 & - \\
\hline & 118 & BDL & $\mathrm{BDL}$ & $\mathrm{BDL}$ & $\mathrm{BDL}$ & 35.0 & 23.0 & BDL. & $\mathrm{BDL}$ & 58 & 2.5 & - \\
\hline \multirow[t]{6}{*}{ E417 } & 104 & $\mathrm{BDL}$ & $\mathrm{BDL}$ & $\mathrm{BDL}$ & BDL & 25.0 & 44.0 & $\mathrm{BDL}$ & $\mathrm{BDL}$ & 69 & 2.5 & - \\
\hline & 105 & BDL & $\mathrm{BDL}$ & $\mathrm{BDL}$ & $\mathrm{BDL}$ & 38.0 & 48.0 & BDL & $\mathrm{BDL}$ & 86 & 2.5 & - \\
\hline & 106 & $\mathrm{BDL}$ & BDL & $\mathrm{BDL}$ & BDL & 10.0 & 18.0 & BDL & $\mathrm{BDL}$ & 28 & 2.5 & - \\
\hline & 107 & BDL & $\mathrm{BDL}$ & $\mathrm{BDL}$ & $\mathrm{BDL}$ & 11.0 & 28.0 & BDL & BDL & 39 & 2.5 & - \\
\hline & 108 & BDL & BDL & BDL & BDL & 17.0 & 57.0 & BDL & BDL & 74 & 2.5 & - \\
\hline & 109 & BDL & BDL & BDL & BDL & 7.2 & 26.0 & BDL & BDL & 33 & 2.5 & - \\
\hline
\end{tabular}


TABLE 1 (Cont.)

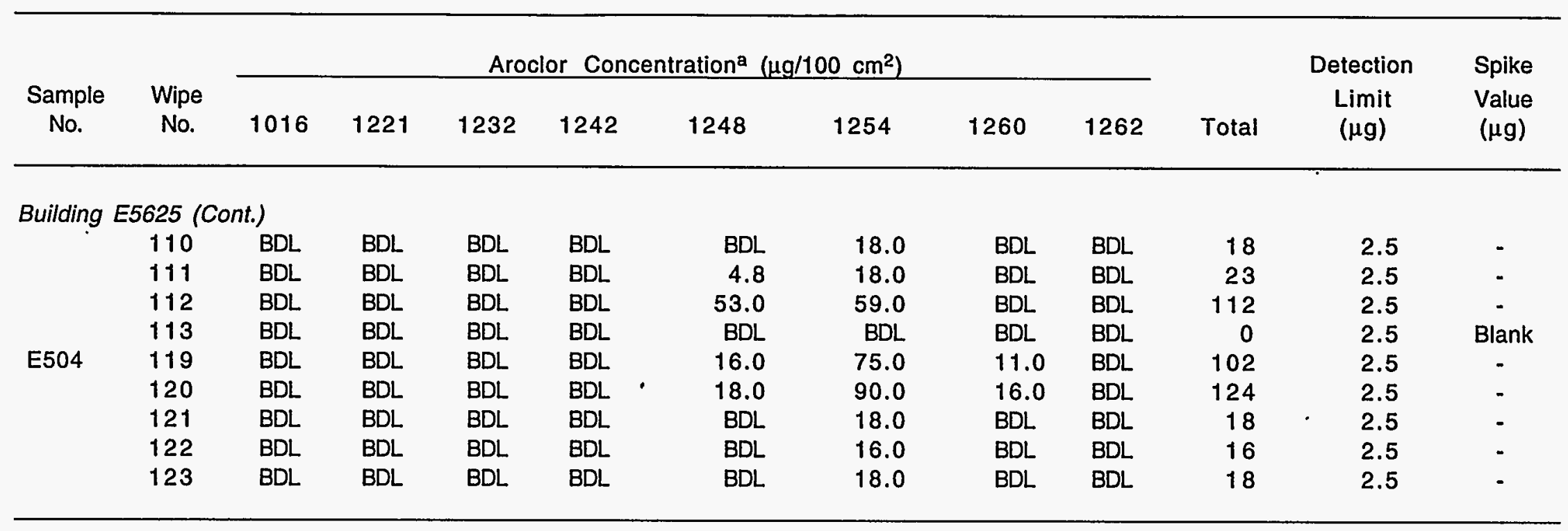

a $\mathrm{BDL}=$ below detection limit. 


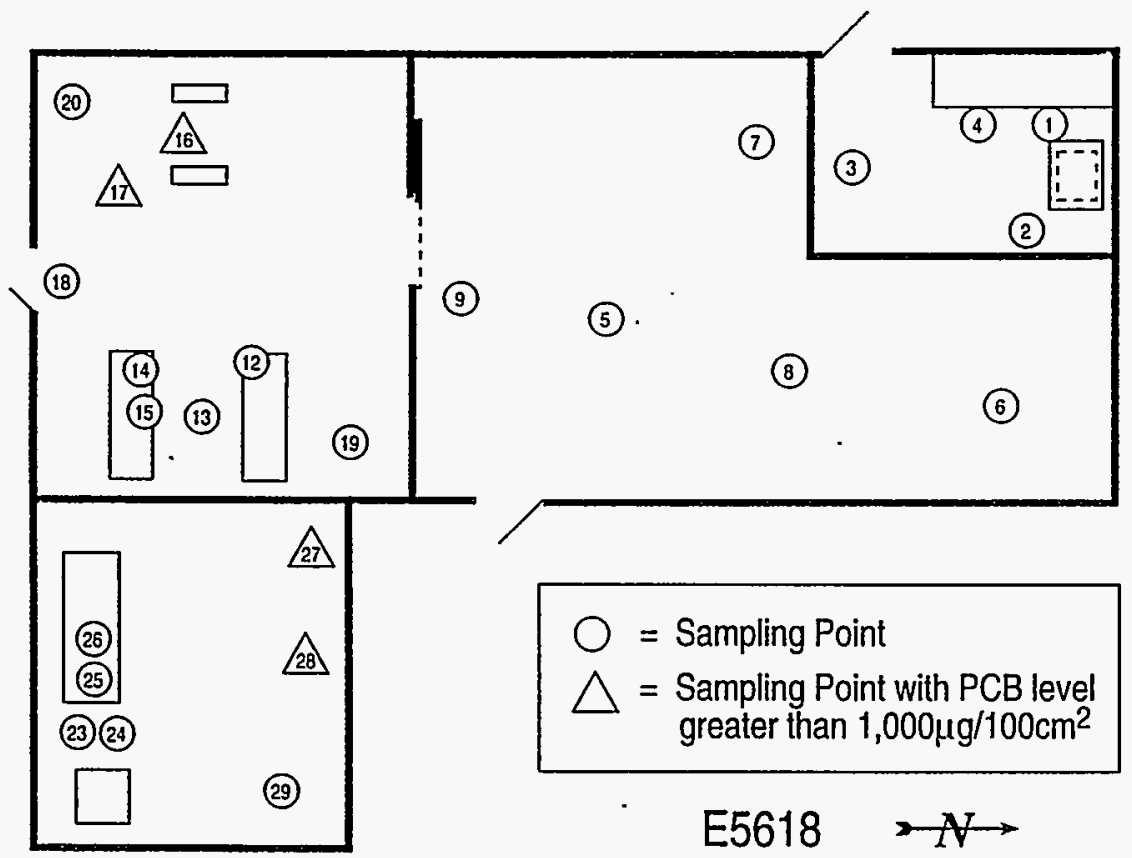

FIGURE 3 Layout of Building E5618, Showing Sampling Points

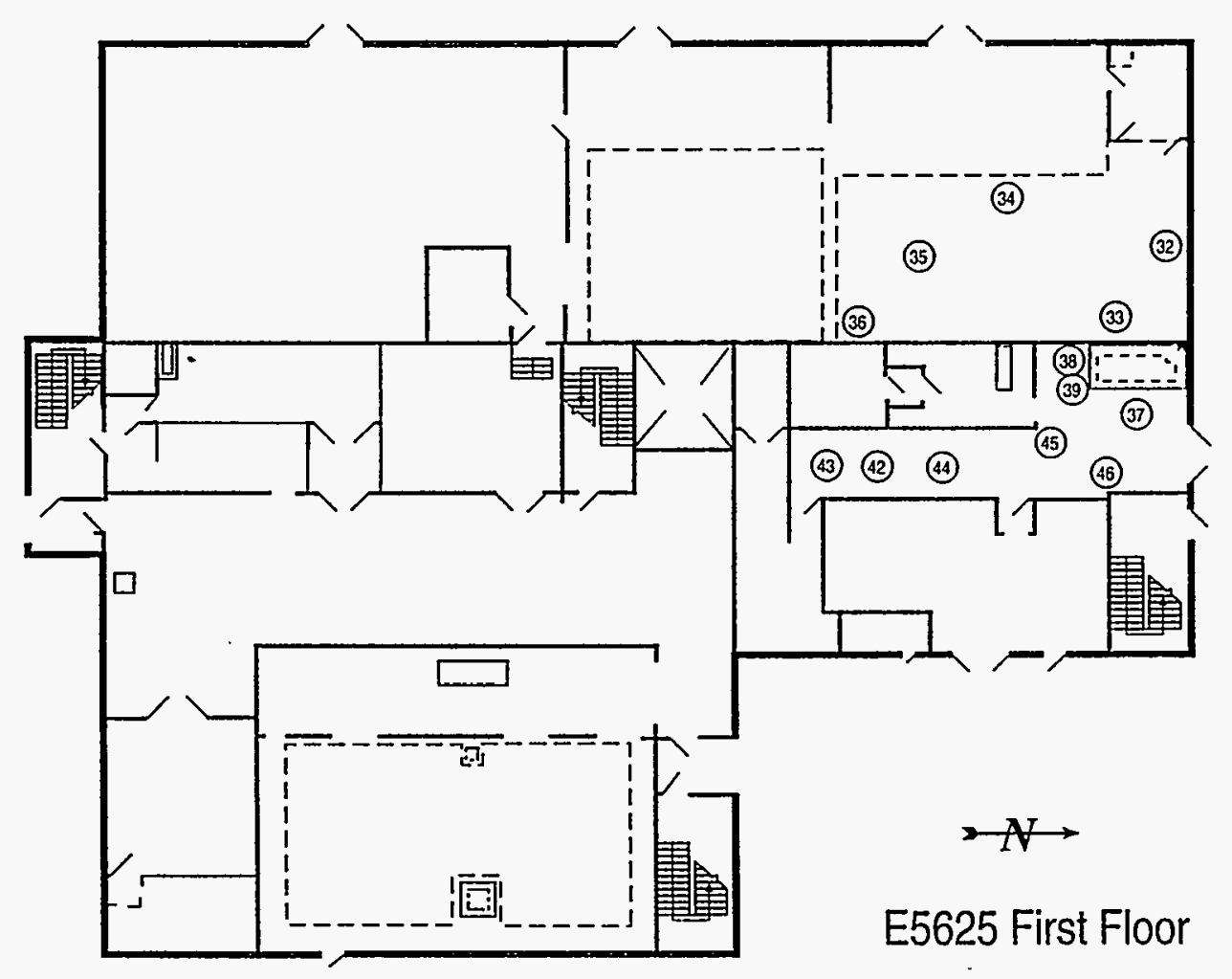

FIGURE 4 Layout of the First Floor of Building E5625, Showing Sampling Points 


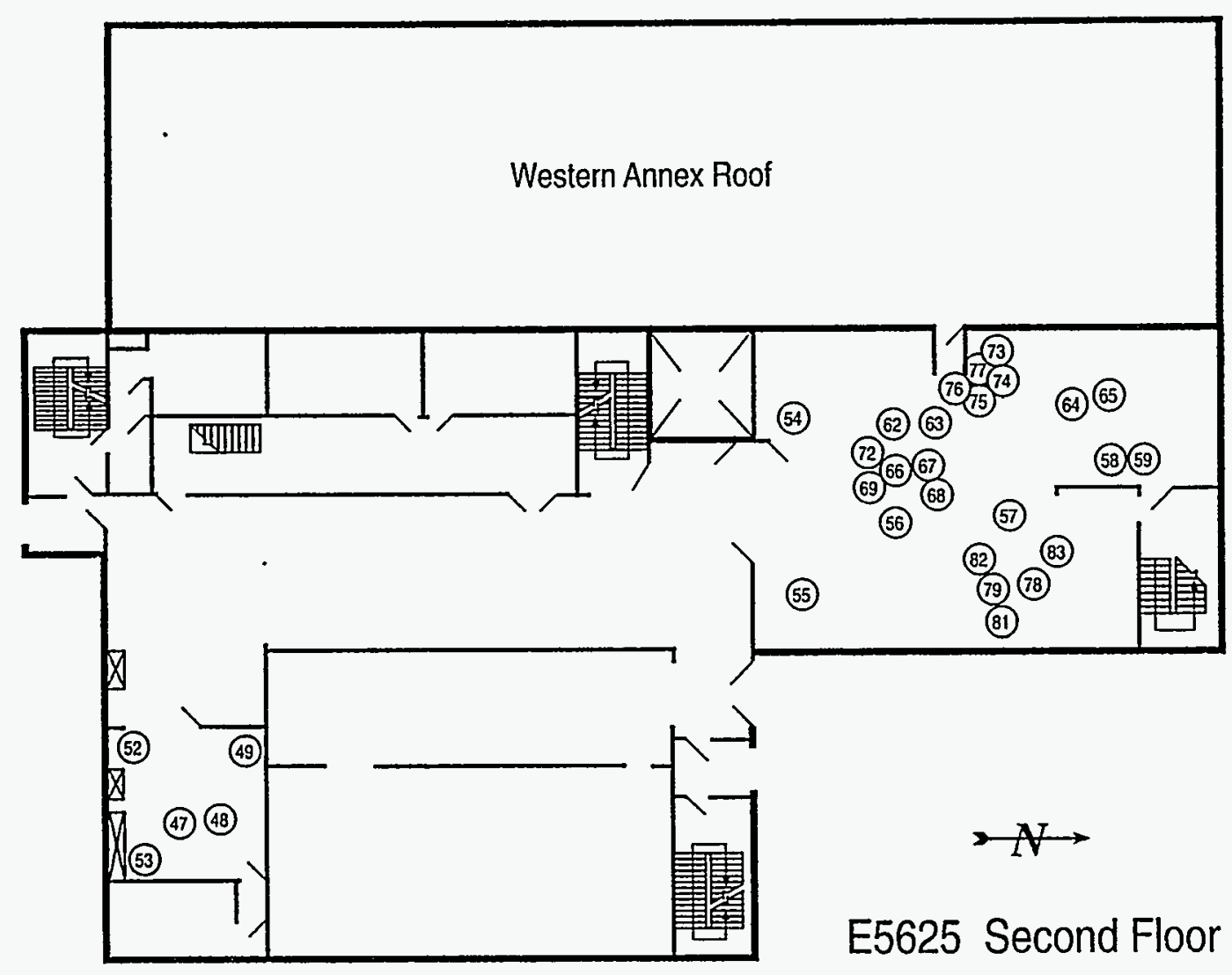

FIGURE 5 Layout of the Second Floor of Building E5625, Showing Sampling Points

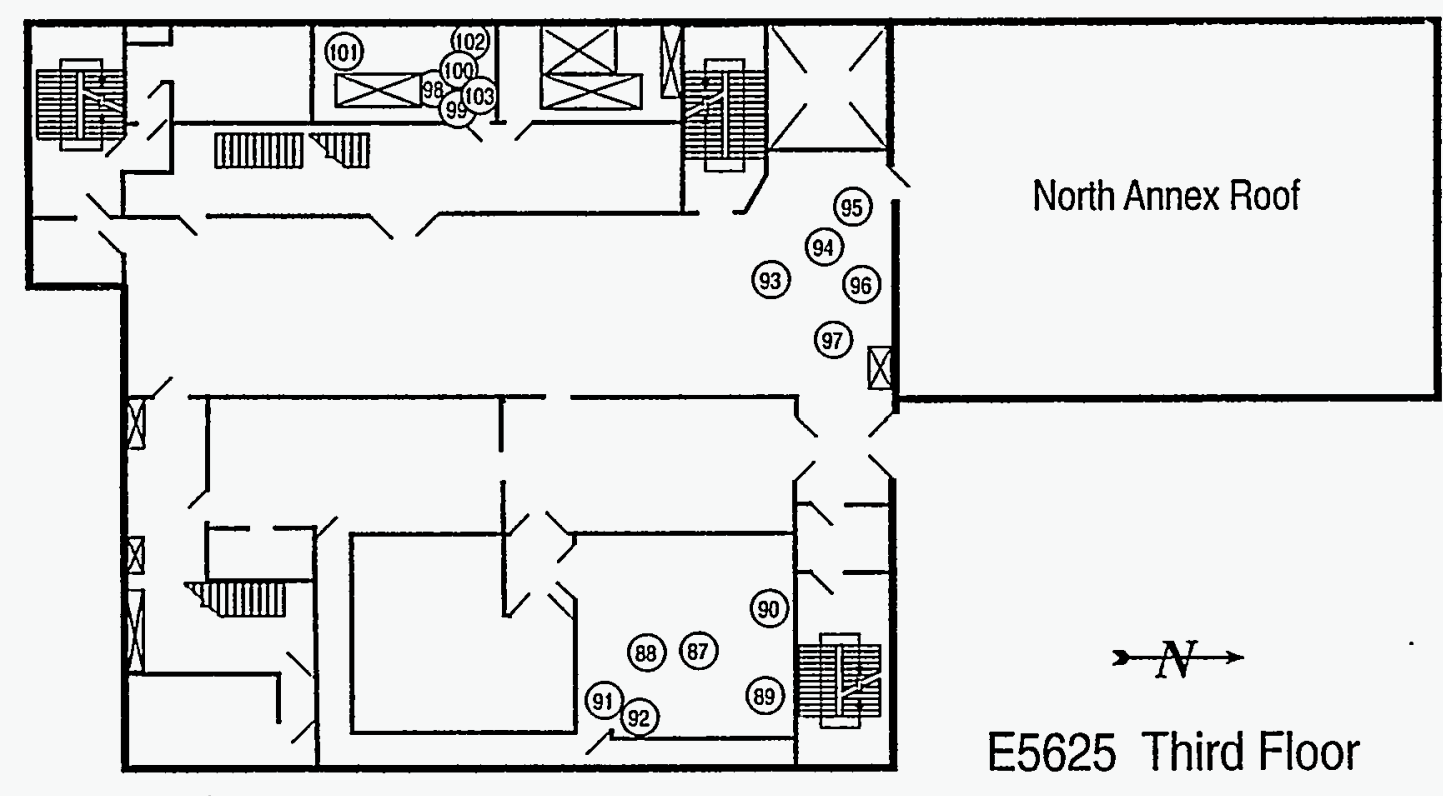

FIGURE 6 Layout of the Third Floor of Building E5625, Showing Sampling Points 

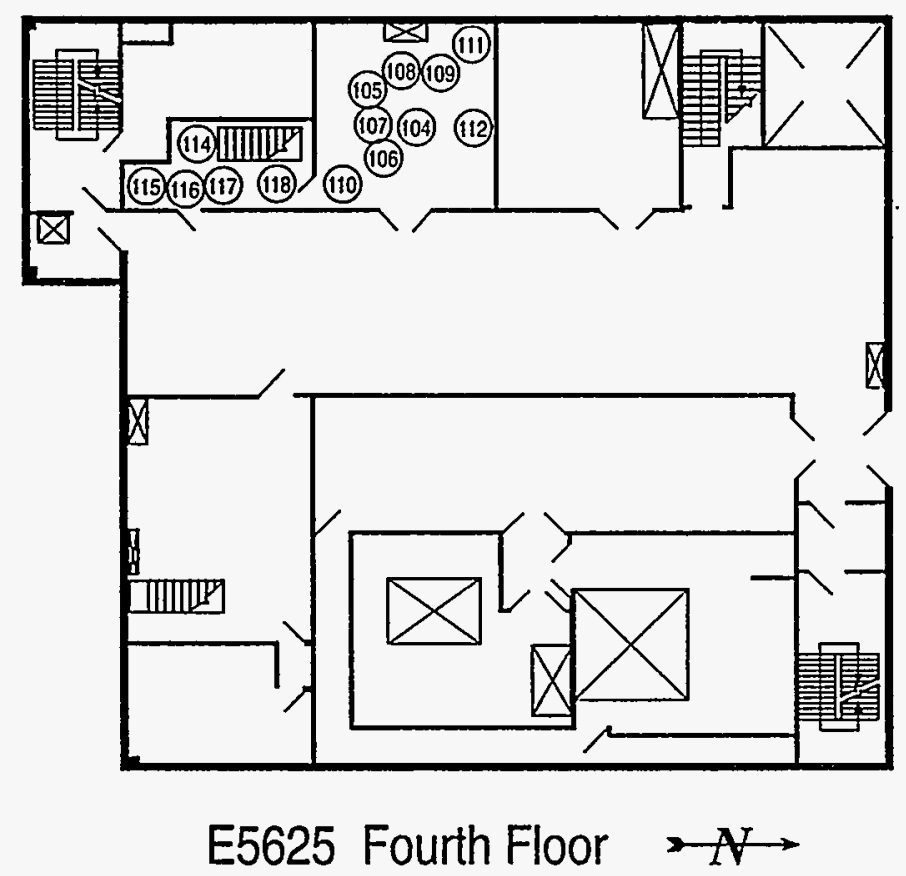

FIGURE 7 Layout of the Fourth Floor of

Building E5625, Showing Sampling Points

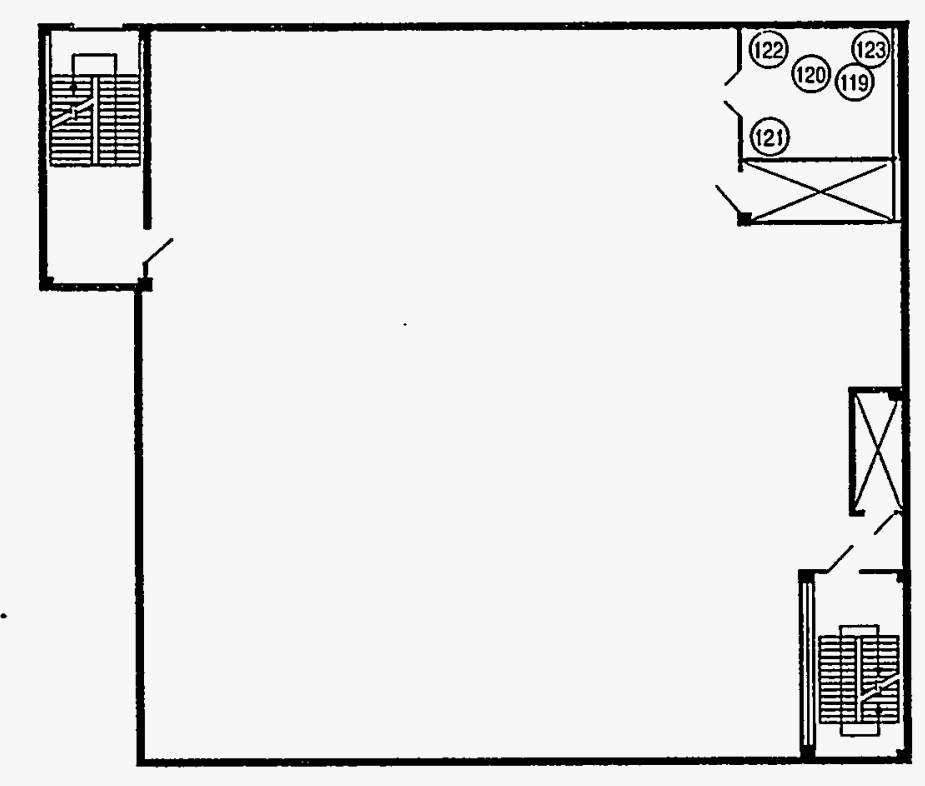

\section{E5625 Roof $\stackrel{N}{\sim}$}

FIGURE 8 Layout of the Roof of Building E5625, Showing Sampling Points 


\section{Quality Assurance/Quality Control}

Field blanks and spiked samples were analyzed as a quality assurance check. The spiked samples (Table 2) were prepared by the Analytical Chemistry Laboratory of ANL. Results indicate that the commercial analytical laboratory did an adequate job identifying and quantitating the PCBs. Aroclor 1016 was misidentified as Aroclor 1242, but the fingerprints of these two Aroclors are very similar. Aroclor 1260 was missed in duplicate samples spiked with $5 \mu \mathrm{g}$, indicating that the limit of detection for Aroclor 1260 is actually higher than the $2.5 \mu \mathrm{g}$ estimated by the commercial analytical laboratory. Field blanks (Table 3 ) showed no evidence of cross contamination in the field or the laboratory.

TABLE 2 Spiked Sample Results

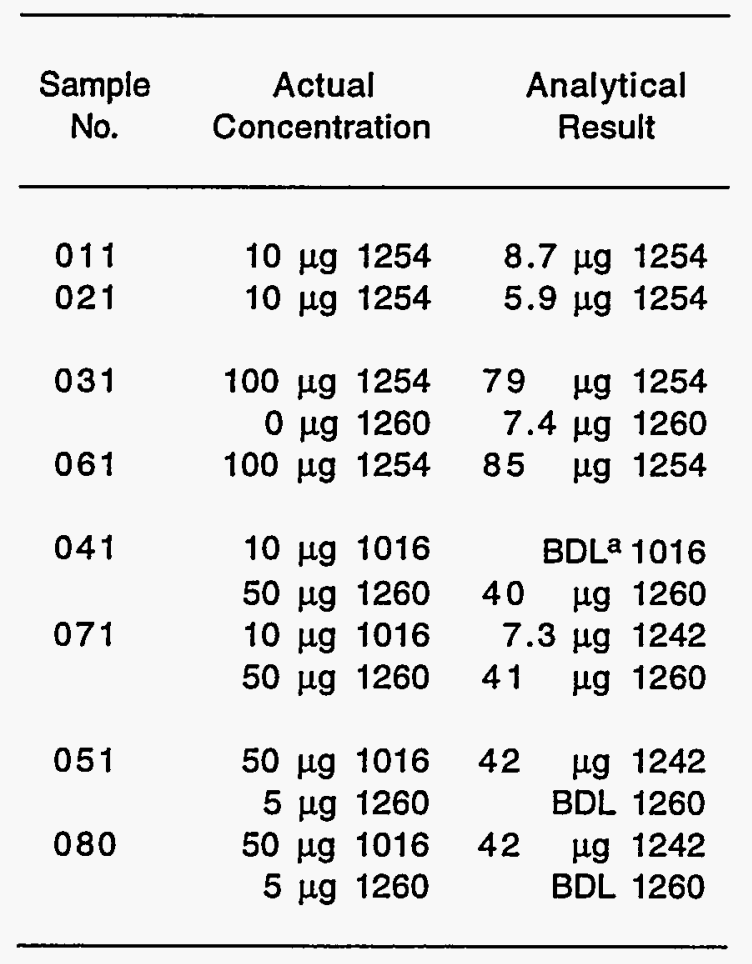

TABLE 3 Field Blank Results

\begin{tabular}{lr}
\hline Sample & $\begin{array}{c}\text { Result } \\
(\mu \mathrm{g} \mathrm{PCB})\end{array}$ \\
\hline & \\
010 & $<2.5$ \\
022 & $<2.5$ \\
030 & $<2.5$ \\
040 & $<2.5$ \\
050 & $<2.5$ \\
060 & $<2.5$ \\
070 & $<2.5$ \\
113 & $<2.5$ \\
\hline
\end{tabular}

a $\mathrm{BDL}=$ below detection limit. 


\section{Conclusions}

The results of the ambient air monitoring indicate that PCBs in the air of the PPC are well below acceptable levels. The wipe-sampling results suggest that the total PCB burden of the PPC appears to be below the 50-ppm regulatory level. However, we have identified contaminated floor surfaces that exceed the approved level of $10 \mu \mathrm{g} / 100 \mathrm{~cm}^{2}$ for a workplace. Areas in Building E5618 exceed $1,000 \mu \mathrm{g} / 100 \mathrm{~cm}^{2}$, with a high reading of $21,100 \mu \mathrm{g} / 100 \mathrm{~cm}^{2}$ in room C103. Building E5625 has several areas where PCBs exceed $100 \mu \mathrm{g} / \mathrm{cm}^{2}$. 


\section{References}

Lattin, F.G., 1994, unpublished information, Edgewood Research and Development Engineering Center, Aberdeen Proving Ground, Md.

O’Neill, H.J., K. Brubaker, and K. Muir-Ploense, 1994, unpublished information, Argonne National Laboratory, Argonne, Ill.

Schneider, J.F., et al., 1995, Air Monitoring for Volatile Organic Compounds at the Pilot Plant Complex, Aberdeen Proving Ground, ANL/ESD/TM-94, Argonne National Laboratory, Argonne, Ill. 